\title{
中性粒子ビーム入射によるミラ一磁場中の ホットイオンのビルドアップと実験装置
}

\author{
谷津潔, 河辺隆也, 三好昭一 \\ （筑波大・物理） \\ ( 51 年 9 月 6 日受理)
}

\section{Abstract}

Buildup of hot-ions by neutral-beam injection into a target plasma in a mirror field is calculated. The main assumption is that the background neutrals which determine the charge-exchange loss time are originated from charge-exchange collision of the injected energetic neutrals with the target plasma. Electric power for confining magnet and pumping speed for evacuation are examined for the experiment of hot-ion buildup.

\section{$\S 1$ は}

ミラー磁場におけるマクロ不安定性は極小磁場を用的るととより安定化でをるととが示され，， 次に問題となっていたミクロ不安定性もアメリカの $2 \mathrm{X}$ アリーズ,ソ連のP P シリーズ等の実験に

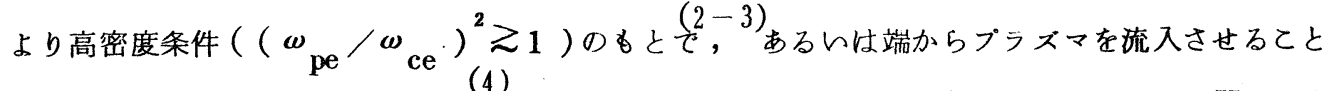
により安定化されるてとが示されだ。 そのようにして安定化された条件のもとでブラズマ閉じ込め 時間の実験式 $\mathrm{n} \tau=2 \cdot 10^{9} \mathrm{~T}_{i}{ }^{\frac{3}{2}}$ が $2 \mathrm{X}$ II Bで得られている。てれはイオンの衝突損失で予想さ れる式と密度, 温度依存性は一致しているが, 值は約 1／3になっている。 上の結果は效場のパルス運転を利用して，プラズマカン等で射されたプラズマを磁場王縮によ

Buildup of Hot-Ions by Neutral-Beam Injection in a Mirror Field and its Experimental Facility.

Kiyoshi YATSU, Takaya KAWABE, and Syoichi MIYOSHI Institute of Physics, University of Tsukuba 
谷津, 河迅, 三好

り高温化したブラズマ,あるいはその中性粒子人射を行って加熱したブラズマについて得られ たのである。開放端系装置の利点である定常運転を達成するためと法定常磁場中で高温プラズマ を生成し，維持するととが必要であり，それがミラ一型装置とよる次の研究課題の1つであると考 えられる。

定常磁場中に中性粒子入射を行ない，ローレンッ電離によってプラズマを生成し，生成されたプ ラズマによる入射粒子の電離によりプラズマをさらにピルドアップさせる実験では不安定性のため $K 10^{10} \mathrm{~cm}^{-3}$ 程度以上の密度は得られていない。战とれを $2 X$ 等の実験と合わせるとミラー磁場中 でプラズマは低密度領域亡高密度領域で安定であり，その間では不安定である。高密度領域での安 定領域は $\omega \mathrm{pe}^{2} / \omega \mathrm{ce}^{2}, \mathrm{R}_{\mathrm{p}} / \mathrm{a}_{\mathrm{i}}$ ( $\mathrm{R}_{\mathrm{p}}$ : ブラズマ半径, $\mathrm{a}_{\mathrm{i}}$ ：イオンのラーマ半径）等の関数とし て理論的計算もなされているが， ${ }^{(6)}$ 現在迄の実験結果を簡単に密度の関数としてまとめると，10 $-10^{13} \mathrm{~cm}{ }^{-3}$ の領域が不安定領域になっている。したがって定常磁場中に高温, 高密度プラズマを 生成するためには，乙の不安定領域を何らかの方法で飛び越さなければならない。

定常磁場中に高温, 高密度プラズマ在生成するためには, 屯ずミラーの端から $100^{13} \mathrm{~cm}^{-3}$ 以上の 高密度プラズマを流入させてターゲットプラズマとし，中性粒子入射によってホットイオンをビル ドアップさせ, 密度が $10{ }^{13} \mathrm{~cm}^{-3}$ 程度以上《なった後プラズマの流入を停止して高温プラズマと入 れ撸えるのが 1 つ有力な方法であると考六られる。

本文ではミラーの端から流入されたターダットプラズマへの中性粒子入射による高温プラズマの ビルドアップイつレて述ヘ，高温プラズマ生成の実験上の問題点を指摘する。

$\S 2$ ホットイオンのビルドアップ

ターゲットブラズマへの中性粒子入射によホットイオンのビルドアップにつんて考察する。タ 一グットブラズマはプラズマの安定性から密度 $\mathrm{n}_{\mathrm{T}}$ は $100^{13} \mathrm{~cm}^{-3}$ 以上あるととが望をしく, 荷電交 換損失時間を長くするためには中性粒子( $\mathrm{H}^{0}$ とする) 密度 $\mathrm{n}_{0}$ との比 $\mathrm{n}_{\mathrm{T}} / \mathrm{n}_{0}$ は 100 以上である ととが要求されるが，プラズマガンにより，あるいは放電等によって作ったプラズマを加熱すると とにより，生成可能であると考えられる。

ターダットプラズマの密度が一定であるとするとホットイオンのビルドアップは次の式で表わさ

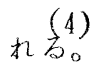

$$
\frac{d n_{H}}{d t}=\frac{2 R_{p} I_{0}}{e V_{p}}\left(n_{H}+n_{T}\right)\left(\sigma_{i}+\alpha \sigma_{x}\right)-\left(n_{H}+n_{T}\right) \frac{1-\alpha}{\tau}
$$


中性粒子ビーム入射によるミラ一磁場中のホットイオンのビルドアッブと実験装置 とてで $n_{H}$ はホットイオンの密度, I $I_{0}$ は高エネルギ一中性粒子( $H^{0}$ のみで考文る)の等価電流, $\mathrm{V}_{\mathrm{p}}$ はプラズマの体積， $\alpha=\mathrm{n}_{\mathrm{T}} /\left(\mathrm{n}_{\mathrm{H}}+\mathrm{n}_{\mathrm{T}}\right), \sigma_{\mathrm{x}}$ は荷電交換の断面積， $\sigma_{\mathrm{i}}$ は電離の断面積で

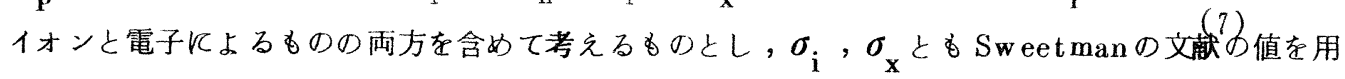

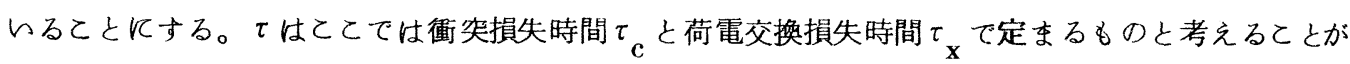
できる。 $\tau_{\mathrm{c}}$ は前に述べ $2 X \| \mathrm{B}$ の実験式を用いて計算する。社在支配する中性粒子は入射中性 粒子ビームとプラズマとの荷電交換で発生するものが大部分であると考えるてとがでをるので（中 性粒子ビーム源からの流入量收荷電交換で発生する量の1／10 以下にするととが可能であると考 えられる）， $\mathbf{n}_{0}$ の時間変化は次式で表わされるものとする。

$$
\frac{d n_{0}}{d t}=\frac{2 R_{p} I_{0}}{e V_{0}}\left(n_{H}+n_{T}\right) \sigma_{x}-n_{0} \frac{2 S}{V_{0}}
$$

こてで $V_{0}$ は真空容器の体積で，Sは排気速度であるが， $\mathrm{H}_{2}$ に対する排気速度を用いるので， $\mathrm{H}^{0}$ に対して2倍にしている。

次飞具体的計算例飞つんて述べ。 プラズマ体積等は半径 $100 \mathrm{~cm}$ の メャンコイルを用んた装置で予想さ れる $2 \mathrm{R}_{\mathrm{p}}=30 \mathrm{~cm}, \mathrm{v}_{\mathrm{p}}=1.4$ $\times 10^{4} \mathrm{~cm}^{3}, \mathrm{~V}_{0}=5 \times 10^{5} \mathrm{~cm}^{3}$ ह し, 灰 $\mathrm{n}_{\mathrm{T}}=1 \times 10^{13} \mathrm{~cm}^{-3}$, $I_{0}\left(H^{0}\right)=100$ Aとする。電子 による $\sigma_{\mathrm{i}}$ は $\mathrm{T} \mathrm{e}=1 \mathrm{keV}$ の值を用 らる。第 1 図には $S=10^{5} \ell / \mathrm{s}$ の場合の $\mathrm{n}_{\mathrm{H}}$ の時間変化が中性粒子 ピームのエネルギー $\mathrm{E}_{0}$ をパラメー タとして示されている。初期压力 $\mathrm{P}_{0}=10^{-7} \mathrm{Torr}$ としているか， ピームエネルギーが低ら場合 $\sigma_{\mathbf{x}} \sigma$ 方が $\sigma_{\mathrm{i}}$ より大をく，人射ビームと プラズマとの荷電交換で発生する中 性粒子の量が多いために真空容器内

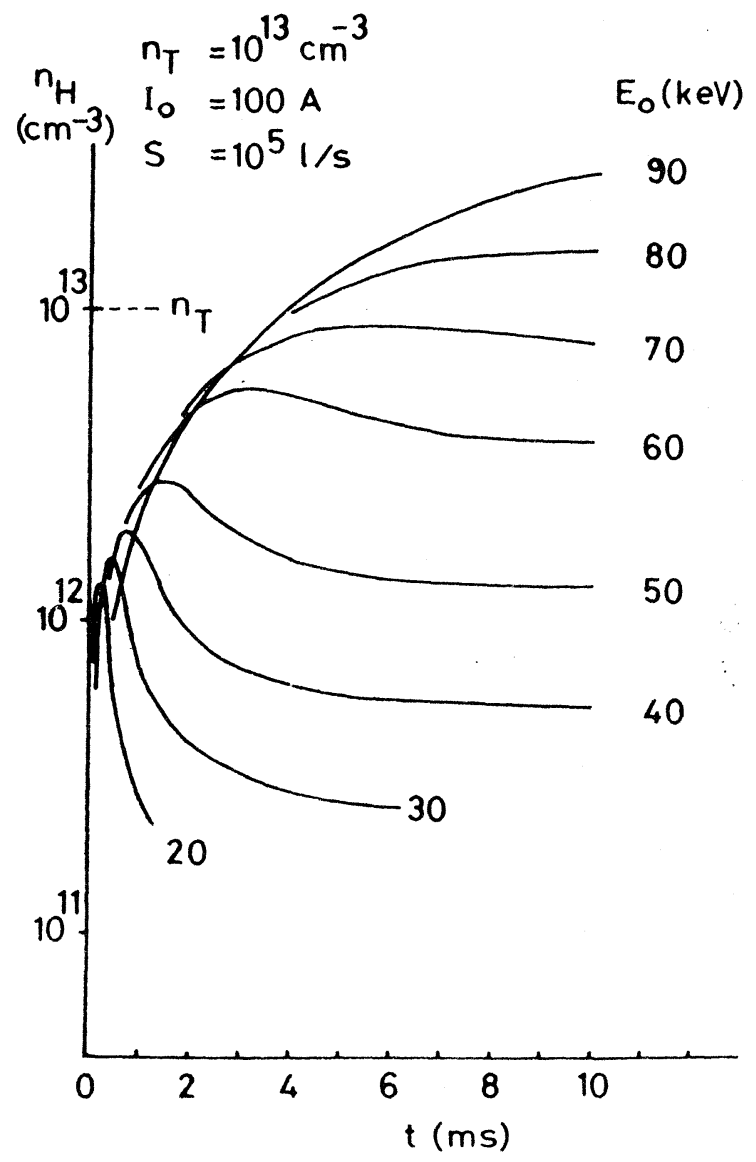

第 1 図ホットイオン密度 $n_{\mathrm{H}}$ の時間変化 


$$
\text { 谷津, 河辺, 三好 }
$$

の压力が急速に上䄯して荷電交換損失時間が减少し, ホットイオンのビルト゚アッブが停止して，さ らに減衰してしまう。第 2 図には $\mathrm{E}_{0}=60 \mathrm{keV}$ の場合の $\mathrm{n}_{\mathrm{H}}$ の時間変化が $\mathrm{S}$ をバンータとして 示されている。

以上第 1 図, 第 2 図より，ターゲットプラズマへの高エネルギー中性粒子ビーム入射により定常 にホットイオンを $10{ }^{\mathbf{3}} \mathrm{cm}^{-3}$ 以上にビルドアップさせるためとは,ビームエネルギーが高く，たと えば $60-70 \mathrm{k} \mathrm{eV}$ 以上で, 真空ポンプの排気速度も非常に大きくなければならないてとがわかる。

\section{$\S 3$ 実験装置}

ミラー磁場による高温ブラズマの 定常閉じ込めを立証するための実験 装置に関して，磁場発生コイル，電 源, 真空ポンプにつんて考察する。

コイルは普通のインャンコイル， すなわち 1800 の半円を組合わせた インャンコイルを用いるすのとする。 半径の比 $\mathrm{R} 2 / \mathrm{R} 1=3$ とすると軸 上のミラー比は約 2.5 である。磁場 、 発生に要する電力を, コイルの大き ら方の半径 R 2 をパラメータとして 中心磁場に対して示すと第 3 図のよ うとなる。ここで電流密度は $\mathrm{B}=$ $20 \mathrm{kG}$ の時 1〜2秒のパルス運転 ができるように $100 \mathrm{~A} / \mathrm{mm}^{2}$ 程度 にしてある。

$$
\text { プラズマ半径 } R_{p} \text { は }(0.1-0.2)
$$

R 2 程度になると考えられるが，

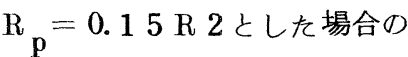
$\mathrm{R}_{\mathrm{p}} / \mathrm{a}_{\mathrm{i}}$ 第3図に示されている。 プラズマがロスコーン不安定性に対 して安定であるためには $\mathrm{R}_{\mathrm{p}} / \mathbf{a}_{\mathbf{i}}$ が

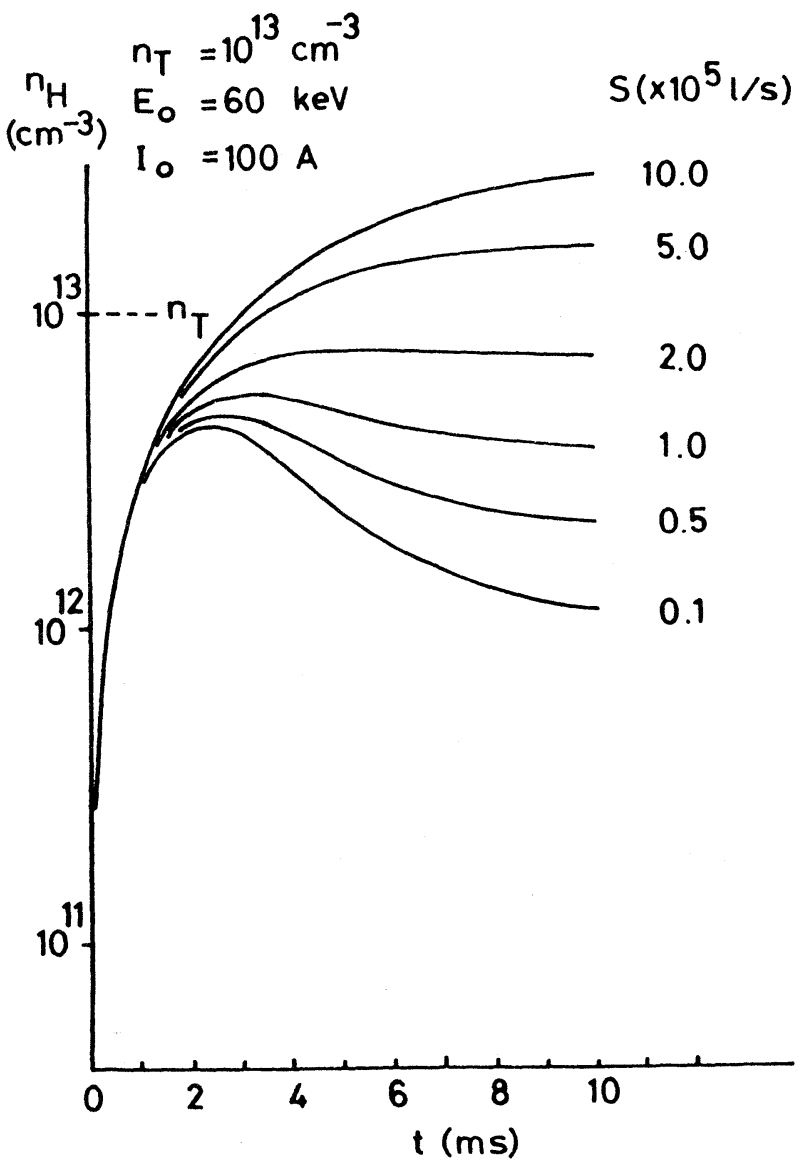

第 2 図 ホットイオン密度 $\mathrm{n}_{\mathrm{H}}$ の時間変化。 排気速度 Sがパラメータ。 
中性粒子ビーム入射にょるミラー磁場中のホットイオンのビルドアップと実験装置 10 程度以上大きいととが要求される が， 2 X】 Bでは $\mathrm{R}_{\mathrm{p}} / \mathrm{a}_{\mathrm{i}}$ が 5 程度 のプラズマも端からブラズマを流入さ せるととにより安定化されるととが示 されているので， $\mathrm{R}_{\mathrm{p}} / \mathrm{a}_{\mathrm{i}}$ は 5 程度以 上あればプラズマを安定に閉じ込める ととができると考えられる。

装置の大きさとしては, 中性粒子入 射,および排気用のポートに要する面 積から考えて, R 2 は $50 \mathrm{~cm}$ 程度以上 あることが望むしい。上に述べたう な条件から，目的とする実験を行なう ためには磁場用電源は $20 \mathrm{MW}$ 程度, できれば $100 \mathrm{MW}$ 以上るととが望 ましん。したがって必要電力, あるい はコイルの熱の問題から最初の実験は 準定常運転にならさるをえないである 5 。

次に真空ポンプについて考える。と の実験を行なうためには $10^{5} \ell / \mathrm{s}$ 以上の排気速度を必要とするが, 真空 容器をコイルの内部に設置する形で考 えると，真空ポンプをコイルの外部に

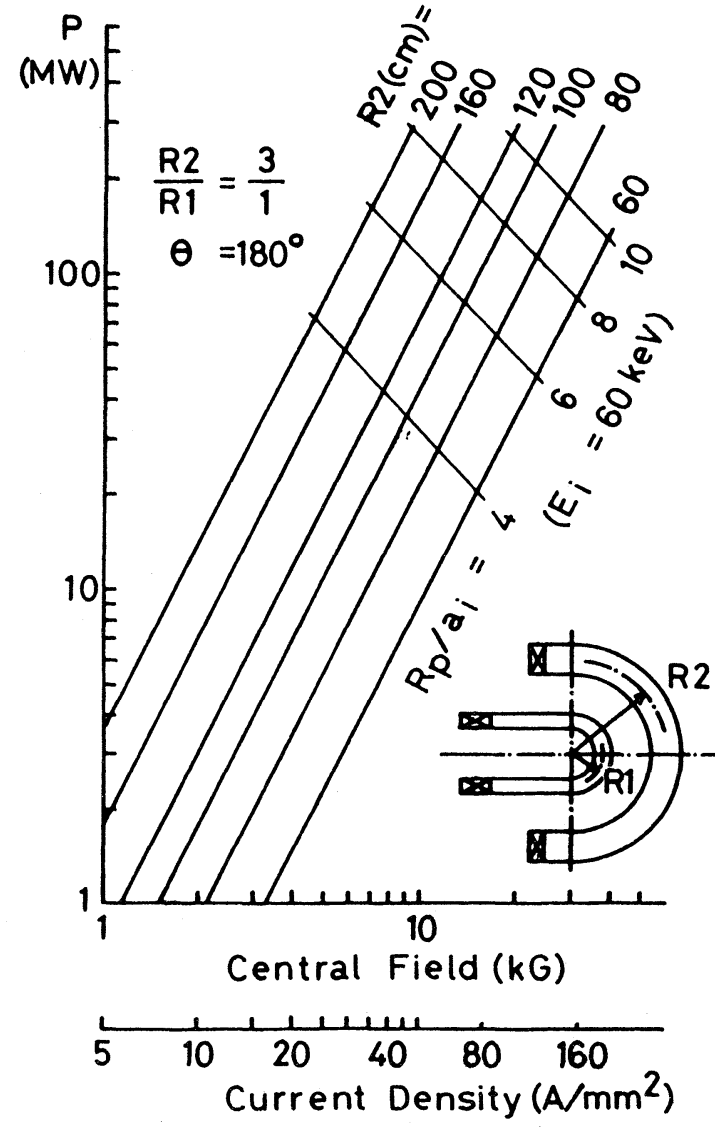

第 3 図 R 2 をパラメータとして, 磁場強度に対して 必要電力を示す。プラズマ半径とイオンラー マ半径の比 $\mathrm{R}_{\mathrm{p}} / \mathrm{a}_{\mathrm{i}}$ \& $\mathrm{E}_{\mathrm{i}}=60 \mathrm{keV}$ の場合 につんて示す。

置いたのでは導管のコンダクタンスのためとれだけの排気速度を得るととは不可能である。したが って容器の面をゲッタ一面，あるいはクライオ面とした形の排気采を考えなければならず，真空ポ ンプの条件からも運転は準定常にならさるを得ないであるう。磁場，および中性粒子ビーム源の定 常運転が実現できたとして，定常の排気でプラズマを維持できるか否かについては，中性粒子の壁 からのリサイクリング関して不明な点が多いためにててで推定することは難かしく，準定常運転 の実験からデータを集積するととが必要であろう。

てれまでは $\mathrm{n}_{\mathrm{T}}$ を $10{ }^{13} \mathrm{~cm}^{-3}$ と仮定して，ビームの減衰長か $2 \mathrm{R}_{\mathrm{p}}$ よりかなり大きい条件で議論 
谷津, 河辺, 三好

を進めてきたのであるか， $2 \mathrm{R}_{\mathrm{p}}$ が减衰長と同程度，あるいはそれより大をくなると，荷電交換て 生じた中性粒子がプラズマ領域から逃げる前に電離衝突老してプラズマ中にトラップされるように なるため，必要な排気速度は小さくてすむよらになる。しかし，密度を高くするためには， $\beta$ 制限 のために，磁場強度を上げなけれげならず，また密度が高くない場合は， $\mathrm{R} p$ を大をくするために コイルを大をくしなけ靲ばならないので, 磁場用電源はさらに大電力のものが必要になる。

\section{$\S 4$ 結 び}

以上ミラー型実験装置による実験の次の課題と考えられる, 定常磁場中での高温ブラズマの生成, 維持を行なら 1つの手段としての，ターゲットブラズマへの高エネルギー中性粒子ビーム入射によ るホットイオンのビルドアップにつんて考察してをた。てれより次のようなととが明らかにされた。

1 ) 中性粒子入射に上りホットイオンを維持するためには, 中性粒子のエネルギーは $60-70$

$\mathrm{keV}$ 程度以上必要であり，エネルギーがそれ以下の場合は莫大な排気速度を必要とする。60 $\mathrm{ke} \mathrm{V}$ 程度の場合でも，真空容器の面全体が排気面になる程の排気速度が必要である。

2 ）乙の実験を行ならための磁場を発生するためとは，20 MW程度以上, 望をしくは $100 \mathrm{MW}$ 程度の電源が必要である。

\section{参考文 献}

1. Yu. V. Gott, M. S. Ioffe and V. G. Tel'kovskii, Nuclear Fusion, Suppl. Part 3, 1045 (1962).

2. J. R. Hiskes, A. H. Futch;

Nuclear Fusion 14 (1974) 116.

3. F. H. Coensgen, W. F. Cummins, A. W. Molvik, W. E. Nexsen, Jr., T. C. Simonen and B. W. Stallard 5th Int. Conf. Plasma Phys. Contr. Fusion Res. (Proc. Conf. Tokyo, 1974) 1, IAEA, CN-33/D2-1.

4. F. H. Coensge, W. F. Cummins, B. G. Logan, A. W. Molvik, W. E. Nexsen, T. C. Simonen, B. W. Stallard, and W. C. Turner, Phys. Rev. Letters 35 (1975) 1501.

5. O. A. Anderson, D. H. Birdsall, C. C. Damm. J. H. Hoote, A. H. Futch, R. K. Goodmar, F. J. Gordon, G. W. Hamilton, E. B. Hooper, A. L. Hunt, J. E. Osher and G. D. Porter, 5th Int. Conf. Plasma Phys. Contr. Fusion Res. (Proc. Conf. Tokyo, 1974) 1, IAEA, CN-33/D5-2. 
中性粒子ビーム入射によるミラー磁場中のホットイオンのビルト゚アップと実験装值

6. D. E. Baldwin, H. L. Berk, L. D. Pearlstein, T. Kammash, and $\mathrm{T}$. Uckan, ibid $\mathrm{CN}-33 / \mathrm{Dl}-1$.

7. D. R. Sweetman, Nuclear Fusion 13 (1973) 157.

8. R. W. Moir and R. F. Post, Nuclear Fusion 9 (1969) 253. 